\title{
Production of biodiesel from Annona muricata seeds
}

\author{
Wai-Leong Wong ${ }^{1,2}$,Waye-Hong $\mathrm{Lim}^{1,2}$, Jet $\mathrm{Si}^{1,2}$, Man-Kee $\mathrm{Lam}^{3,4}$, and Yeek-Chia Ho ${ }^{1,2, *}$ \\ ${ }^{1}$ Civil and Environmental Engineering Department, Universiti Teknologi PETRONAS, 32610 Seri \\ Iskandar, Perak, Malaysia. \\ ${ }^{2}$ Centre for Urban Resource Sustainability, Institute of Self-Sustainable Building, Universiti \\ Teknologi PETRONAS, 32610 Seri Iskandar, Perak, Malaysia. \\ ${ }^{3}$ Chemical Engineering Department, Universiti Teknologi PETRONAS, 32610 Seri Iskandar, Perak, \\ Malaysia. \\ ${ }^{4}$ Centre for Biofuel and Biochemical Research, Institute of Self-Sustainable Building, Universiti \\ Teknologi PETRONAS, 32610 Seri Iskandar, Perak, Malaysia.
}

\begin{abstract}
Biodiesel is one of the effective alternative fuels to overcome the problems associated with environmental issues and energy crisis. However, the production of biodiesel from edible oil has provoked the food versus fuel dispute. Thus, a non-edible crop, Annona muricata, is selected as the raw material to produce oil for biodiesel production. In this study, A. muricata oil was extracted with n-hexane at $70^{\circ} \mathrm{C}$ for $6 \mathrm{~h}$. Subsequently, the oil was transesterified with methanol and potassium hydroxide $(\mathrm{KOH})$ to produce biodiesel. The significance of transesterification parameters including temperature, time, catalyst concentration, and oil-to-methanol ratio on biodiesel yield (\%) was established through two-level factorial design. The factorial design shows that all parameters are significant. Besides, the high content of monounsaturated fatty acid (oleic acid) in the resultant biodiesel suggests that $A$. muricata biodiesel could display good fuel quality. This hypothesis is proven by the excellent calorific value (39.21 $\left.\mathrm{MJ} \mathrm{kg}^{-1}\right)$.
\end{abstract}

\section{Introduction}

The world population has grown rapidly in recent years. According to the Population Reference Bureau [1], the world population will increase by $31 \%$ and reach 9.8 billion in 2050. Due to this, the world will experience a surging demand towards energy in the future. Fossil fuel as the primary energy source has contributed $80 \%$ to the total energy demand, in which $58 \%$ is used in the transportation sector [2]. However, the sources of fossil fuel around the world are depleting rapidly [3]. Furthermore, fossil fuel is the major cause of global warming and many other environmental impacts.

\footnotetext{
*Corresponding author: yeekchia.ho@utp.edu.my; yeekchia@yahoo.com
} 
Biodiesel is one of the efficient alternative fuels to replace conventional petroleum fuel [3]. The advantages of biodiesel compared to conventional diesel are low smoke and particulates, low carbon dioxide emission, high cetane number, and others [4]. Currently, transesterification is the most favourable process to convert animal fats and vegetable oils (i.e., triacylglycerols) to biodiesel [3].

Currently, more than $95 \%$ of biodiesel is produced from edible oils such as palm oil, soybean oil, and sunflower oil, which are easily available on a bulk scale from the agricultural industry. However, this situation has raised the concern that the feedstock may compete with food materials, for instance, the food versus fuel debate. Hence, attention has shifted to nonedible oils including Jatropha curcas L., Pachira glabra, and Moringa oleifera [5]. However, the cultivation of biodiesel feedstock renders it economically uncompetitive with petroleumbased fuels as the cultivation of feedstock requires costly resources such as land and water [6]. Additionally, the expansion of agricultural land for the growth of feedstock could result in biodiversity loss, deforestation, and increasing carbon emissions from altering the land usage [7]. Moreover, the increased use of water and land would create waste with high nitrogen levels and cause toxicity, eutrophication, and oxygen consumption. Hence, in selecting the suitable feedstock, it is suggested that focus should be given on waste products [6]. Besides, according to Anastas and Warner [8], the use of renewable feedstock is one of the principles to produce a greener chemical, process, or product. This is because the cost of feedstock contributed to $70 \%-95 \%$ of the total production costs [9]. Therefore, biodiesel produced from renewal feedstock or waste products could significantly reduce the overall production costs.

Therefore, in this study, Annona muricata (soursop) seed is selected as the feedstock. This plant is receiving a lot of attention recently due to the extensive usage in the medical area such as for hypoglycemic, hypotensive, and cancer treatment [10]. Thus, the by-products of the plant, e.g., seeds, are available in abundance, which makes it favourable for producing biodiesel [11-12]. A. muricata is widely cultivated in tropical areas throughout the world, including Southeast Asia and southern Florida. Particularly in tropical countries such as Malaysia, soursop is found to be one of the fruits that contribute significantly to the economic growth. Due to its pleasant smell and taste, the pulp can be consumed fresh or served in the form of juice, ice cream, and candy [10].

Hence, the objective of this research is to determine the suitability of $A$. muricata seed oil as a potential source for biodiesel production. This was achieved by determining the significant parameters for the transesterification process. Besides, the characterisation of biodiesel was carried out to determine the functional groups, fatty acid compositions, and fuel properties of the produced biodiesel.

\section{Material and methods}

\subsection{Preparation of feedstock}

A. muricata seeds (Figure 1) were collected and washed using tap water to remove particles. The cleaned seeds were dried under the sun for at least $4 \mathrm{~h}$. Subsequently, the seeds 
were milled with a grinding machine. Afterwards, the ground seeds were sieved to acquire the desired sizes.

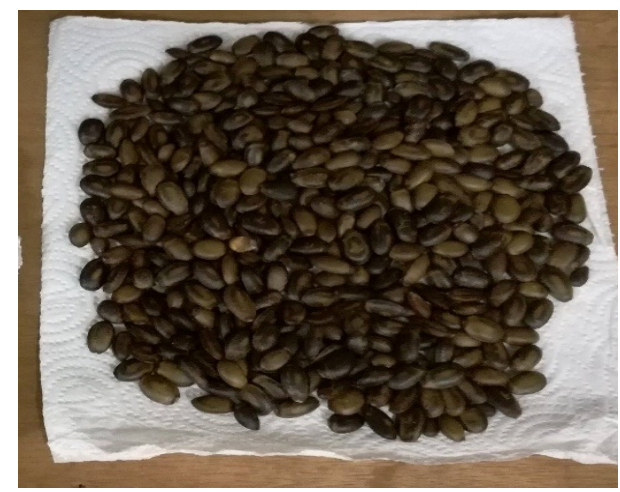

Fig. 1. A. muricata seeds.

\subsection{Extraction of Annona muricata oil}

The extraction was carried out using a Soxhlet extractor under the optimised extraction conditions determined from the previous study. The optimised conditions for the extraction are $200 \mathrm{ml}, 6 \mathrm{~h}, 5 \mathrm{~g}, 0.71 \mathrm{~mm}$, and $72{ }^{\circ} \mathrm{C}$ of solvent volume, extraction time, sample weight, sample size, and operating temperature, respectively. The sample with the desired weight was placed in a cellulose thimble and fed to the Soxhlet extractor. The solvent used for the extraction was $n$-hexane. The entire setup was heated in a heating mantle under the constant temperature $\left(72{ }^{\circ} \mathrm{C}\right)$. After the extraction, the solvent was evaporated at $80-90{ }^{\circ} \mathrm{C}$ to evaporate $\mathrm{n}$-hexane and recover the oil.

\subsection{Experimental design}

Various parameters have to be optimised for the transesterification reaction including reaction temperature, reaction time, catalyst concentration, and oil-to-methanol ratio. It is difficult and impractical to isolate and test each variable individually. Therefore, Design Expert software was employed, where the optimisation started with factorial design to identify the key parameters affecting the reaction that produced the highest yield and desired fatty acid component.

A two-level factorial design was employed. Temperature (A), reaction time (B), catalyst concentration (C), and oil-to-methanol ratio (D) were selected as the independent variables. The response chosen was the percentage of biodiesel produced and oleic acid. 16 experimental runs were determined by Design Expert software.

\subsection{Transesterification reaction}

The transesterification experiments were conducted using a reflux condenser under different conditions. The prepared chemicals $(\mathrm{w} / \mathrm{w})$ of potassium hydroxide $(\mathrm{KOH})$ and methanol $\left(\mathrm{CH}_{3} \mathrm{OH}\right)$ for molar ratio-to-oil parameter was added to the oil. The mixture was heated at the desired temperature for a defined time under continuous stirring using a magnetic stirrer. Subsequently, the product from the transesterification was allowed to settle 
for $24 \mathrm{~h}$ to separate fatty acid methyl ester (FAME) and glycerol layers. The percentage of biodiesel yield was determined by the weight of biodiesel layer with the weight of $A$. muricata oil used. Furthermore, the oleic acid percentage was determined by gas chromatography (GC).

\subsection{Gas chromatography analysis}

The fatty acid composition of biodiesel was identified using gas chromatography (GC PerkinElmer Clarus 680).

\subsection{Biodiesel fuel properties}

The biodiesel fuel properties were tested by the Intertek Testing Laboratories. Two biodiesel fuel properties were evaluated in this study. Meanwhile, calorific value was evaluated in accordance to ASTM D240.

\section{Results and discussion}

\subsection{Factorial design}

The significance of the factors, namely temperature (A), reaction time (B), catalyst concentration (C), and oil-to-methanol ratio (D) was evaluated using a two-level factorial design. The biodiesel yield was studied. The result of analysis of variance (ANOVA) for the transesterification reaction is given in Table 1 . All the terms with $p$-value smaller than 0.05 are considered as significant. Thus, $\mathrm{B}, \mathrm{C}$, and $\mathrm{AD}$ are significant.

Table 1. The results of analysis of variance for transesterification reaction (yield \%).

\begin{tabular}{|l|l|l|l|l|l|}
\hline Source & $\begin{array}{l}\text { Sum of } \\
\text { Squares }\end{array}$ & df & $\begin{array}{l}\text { Mean } \\
\text { Square }\end{array}$ & $F$-value & $\begin{array}{l}p \text {-value } \\
\text { Prob }>F\end{array}$ \\
\hline Model & 15197.00 & 5 & 3039.40 & 5.19 & 0.0132 \\
\hline Temperature & 30.03 & 1 & 3.03 & 0.051 & 0.8254 \\
\hline Reaction time & 7276.94 & 1 & 7276.94 & 12.42 & 0.0055 \\
\hline Catalyst concentration & 2928.97 & 1 & 2928.97 & 5.00 & 0.0493 \\
\hline Oil-to-methanol ratio & 23.18 & 1 & 23.18 & 0.040 & 0.8463 \\
\hline $\begin{array}{l}\text { Interaction between } \\
\text { temperature and oil- } \\
\text { to-methanol ratio }\end{array}$ & 4937.87 & 1 & 4937.87 & 8.43 & 0.0157 \\
\hline Residual & & & & & \\
\hline Cor. Total & 21054.76 & 15 & & & \\
\hline
\end{tabular}




\subsection{Fatty acid composition of biodiesel}

Fatty acid composition of biodiesel is a key element that influences the properties of the produced FAME. The fatty acid profile of $A$. muricata biodiesel is very close to Jatropha curcas $L$. biodiesel. The biodiesel produced from both sources consist of high percentages of monounsaturated fatty acid (i.e. oleic acid). A. muricata biodiesel consists of $47.02 \%$ of oleic acid, whereas Jatropha curcas L. biodiesel has $45.79 \%$ of oleic acid. Furthermore, $A$. muricata biodiesel consists of $23.55 \%$ of saturated fatty acid and $76.96 \%$ of unsaturated fatty acid. On the other hand, the saturated fatty acid and unsaturated fatty acid contents of Jatropha curcas L. biodiesel are $18.82 \%$ and $78.06 \%$, respectively. Jatropha curcas $L$. biodiesel have similar characteristics to petroleum diesel [13]. Thus, the high similarity of the fatty acid composition of A. muricata biodiesel with Jatropha curcas L. biodiesel indicates that $A$. muricata seeds could be the potential feedstock for biofuel development.

\subsection{Biodiesel fuel properties}

Calorific value of fuel is one of the important properties as it could affect fuel consumption. Generally, calorific value is the measure of fuel energy content. A fuel with high calorific value is able to generate greater engine power output for a given amount of fuel consumed. The calorific value of $A$. muricata biodiesel was $39.21 \mathrm{MJ} \mathrm{kg}^{-1}$. This is higher than the values for Annona diversifolia biodiesel and comparable with Jatropha curcas $L$. and Moringa peregrine biodiesel.

Table 1. Fuel properties of A. muricata biodiesel.

\begin{tabular}{|l|l|l|l|l|}
\hline Fuel Properties & $\begin{array}{l}\text { This } \\
\text { Study }\end{array}$ & $\begin{array}{l}\text { Jatropha } \\
\text { curcas L. }^{[14]}\end{array}$ & $\begin{array}{l}\text { Moringa } \\
\text { peregrine }^{[13]}\end{array}$ & $\begin{array}{l}\text { Annona } \\
\text { diversifolia }^{[15]}\end{array}$ \\
\hline $\begin{array}{l}\text { Calorific Value } \\
\left(\mathrm{MJ} \mathrm{kg}^{-1}\right)\end{array}$ & 39.21 & 40.427 & 40.119 & 36.30 \\
\hline
\end{tabular}

\section{Conclusion}

In conclusion, biodiesel is successfully produced from a novel feedstock, A. muricata seeds in this study. The seeds are able to produce approximately $20 \%-30 \%$ of oil by using nhexane solvent extraction method. Subsequently, the oil can be easily converted to biodiesel through one-step base-catalysed transesterification reaction. In addition, the two-level factorial design confirms that the parameters including temperature, time, catalyst concentration, and oil-to-methanol ratio are significant on biodiesel yield.

Furthermore, the results from the GC analysis also display high content of monounsaturated fatty acid. With that, it could be hypothesised that the biodiesel produced might possess good fuel quality. This hypothesis is then supported by the calorific value of the produced biodiesel.

As a conclusion, A. muricata seeds could be a potential material to produce biodiesel. Moreover, with the added advantage of the broad range of medical usage, A. muricata is believed to become a promising source for sustainable production of biodiesel in the near future. 
The authors would like to express their sincere gratitude to Universiti Teknologi PETRONAS for funding this project under YUTP grant (0153AA-E34). This work was supported by the Institute of Self-Sustainable Building and Civil and Environmental Engineering Department. We would also like to acknowledge the support from Mdm. Norhayama bt. Ramli and Mr. Muhammad Jamal Hamizi b. Zulkafli for their help on equipment handling and technical assistance in the Environmental Laboratory and Environmental Research Laboratory, as well as the Centralised Analytical Laboratory (CAL) for their assistance in characterisation studies.

\section{References}

1. Population Reference Bureau. (2017). Retrieved 25 October, 2017, from http://www.prb.org/Publications/Datasheets/2017/2017-world-population-datasheet.aspx

2. N. Gaurav, S. Sivasankari, G. S. Kiran, A. Ninawe, J. Selvin, Renewable and Sustainable Energy Reviews, 73 (2017)

3. M. Salaheldeen, M. K. Aroua, A. A. Mariod, S. F. Cheng, M. A. Abdelrahman, Atabani, A. E. Energy Conversion and Management, 92 (2015)

4. M. R. Mohan, R. C. R. Jala, S. S. Kaki, R. B. N. Prasad, B. V. S. K. Rao, Industrial Crops and Products, 90 (2016)

5. W, Roschat, T, Siritanon, B. Yoosuk, T. Sudyoadsuk, V. Promarak, Renewable Energy, 101 (2017).

6. V. Najdanovic-Visak, F. Y.-L, Lee, M. T. Tavares, A. Armstrong, Journal of Environmental Chemical Engineering, 5 (2017).

7. Chin, M. (2011). Retrieved 17 June 2017, 2017, from http://www.cifor.org/publications/pdf_files/WPapers/WP64CIFOR.pdf

8. P., Anastas, J. Warner, (1998). Retrieved 20 June 2017, from https:/www.acs.org/content/acs/en/greenchemistry/what-is-greenchemistry/principles/12-principles-of-green-chemistry.html

9. M. M. K. Bhuiya, M. G. Rasul, M. M. K., Khan, N. Ashwath, A. K. Azad, Renewable and Sustainable Energy Reviews, 55 (2016)

10. A. V. Coria-Téllez, E. Montalvo-Gónzalez, E. M. Yahia, E. N. Obledo-Vázquez, Arabian Journal of Chemistry. 11 (2016)

11. R. Dongre, (2014). Inter J Univers Pharm Biosci, 3 (2014)

12. P. Schroeder, B. P. d. Nascimento, G. A. Romeiro, M. K.-K. Figueiredo, M. C. d. C. Veloso, Journal of Analytical and Applied Pyrolysis, 124 (2017).

13. A. B. Chhetri, M. S. Tango, S. M. Budge, K. C. Watts, M. R. Islam, International Journal of Molecular Sciences, 9 (2008)

14. H. C. Ong, A. S. Silitonga, H. H. Masjuki, T. M. I. Mahlia, W. T. Chong, M. H. Boosroh, Energy Conversion and Management, 73 (2013)

15. B. Reyes-Trejo, D. Guerra-Ramírez, H. Zuleta-Prada, J. A. Cuevas-Sánchez, L. Reyes, A, Reyes-Chumacero, Industrial Crops and Products, 52 (2014) 